\title{
Adenine nucleotide concentrations in patients with erythrocyte autoantibodies
}

\author{
VF STRONG, RJ SOKOL, SA RODGERS, S HEWITT \\ From the Regional Blood Transfusion Centre, Sheffield
}

SUMMARY Erythrocyte adenine nucleotide concentrations were measured in 154 patients with erythrocyte autoantibodies and 811 normal subjects using a luciferin-luciferase bioluminescent assay. The patients were initially divided into haemolysing and non-haemolysing groups. Red cell adenosine triphosphate (ATP) concentrations were significantly raised in the 96 patients with active haemolysis compared with the normal subjects and with the 58 patients in the nonhaemolysing group. Although the patients categorised as non-haemolysing had higher ATP values than the normal subjects, this was because several patients had the anaemia of chronic disorders, which is associated with a shortened red cell life. Measurement of red cell ATP was a useful indicator of mean erythrocyte age and a raised value in patients with erythrocyte autoantibodies reflected active haemolysis.

In patients with erythrocyte autoantibodies it is important to decide whether active haemolysis is present. The simpler and indirect methods of assessing this-for example, haptoglobin concentrations and reticulocyte counts-are sometimes unhelpful,' particularly when the clinical condition is complicated. Definitive isotopic measurement of red cell life span is time consuming and requires expensive counting equipment. Erythrocyte adenine nucleotide concentrations decline with cell age ${ }^{2}$ and the present study was undertaken to investigate whether measurement of these substances, particularly ATP, would be of value in assessing red cell life span in patients in whom autoimmune haemolysis was suspected.

\section{Material and methods}

Studies were carried out on blood samples from 154 adult patients with erythrocyte autoantibodies referred for investigation of possible autoimmune haemolysis and on samples from 811 normal subjects. The latter individuals were all in good health and were not taking any medication. The patients were categorised as haemolysing or nonhaemolysing from the results of standard investigations including serological findings, haemoglobin concentration, reticulocyte count, blood film appearances, the presence of marrow erythroid

Accepted for publication 23 January 1985 hyperplasia, red cell life span, and measurement of serum haptoglobins, bilirubin, and lactic dehydrogenase.

Red cell adenosine triphosphate (ATP) and adenosine diphosphate (ADP) concentrations and the ATP to ADP ratios were determined using a previously described bioluminescent luciferinluciferase system. ${ }^{3}$ Blood samples, anticoagulated with potassium edetic acid, were examined at different times, from within $4 \mathrm{~h}$ of collection (day 0 ) until $96 \mathrm{~h}$ (day 4), at roughly $24 \mathrm{~h}$ intervals; storage between times was at $4^{\circ} \mathrm{C}$. Nearly 200 of the samples from the normal subjects were tested at all intervals. Lysates were made and either tested immediately or frozen for examination later. ${ }^{3}$ The effect of age and sex was assessed in the normal subjects by comparing the findings in 10 men and 18 women aged 18-25 years and 10 men and 14 women of 50-65 years.

Standard statistical methods were used; means and their standard errors were calculated and differences between means were tested for significance ( $p$ $<0.05)$ by Student's $t$ test.

\section{Results}

Red cell ATP and ADP concentrations and the ATP to ADP ratios for the normal subjects at each interval of testing are shown in Table 1; the age and sex of the subject had no effect on the results $(p>0.5$ in all instances). 
Table 1 Red cell adenosine triphosphate $(A T P)$ and adenosine diphosphate $(A D P)$ concentrations and ATP to ADP ratios for normal subjects

\begin{tabular}{|c|c|c|c|c|c|c|}
\hline Time of testing & $A T P(\mu \mathrm{mol} / \mathrm{ml})$ & $(n)$ & $A D P(\mu \mathrm{mol} / \mathrm{ml})$ & $(n)$ & $A T P: A D P$ & $(n)$ \\
\hline $\begin{array}{l}\text { Day } 0 \\
\text { Day } 1 \\
\text { Day } 2 \\
\text { Day } 3 \\
\text { Day } 4\end{array}$ & $\begin{array}{l}1.52 \pm 0.02 \\
1.35 \pm 0.02 \dagger \\
1.24 \pm 0.02 \dagger \\
1 \cdot 16 \pm 0.02^{*} \\
1.10 \pm 0.02\end{array}$ & $\begin{array}{l}(197) \\
(811) \\
(178) \\
(180) \\
(178)\end{array}$ & $\begin{array}{l}0.30 \pm 0.01 \\
0.25 \pm 0.01 \\
0.24 \pm 0.02 \\
0.28 \pm 0.02 \\
0.28 \pm 0.01\end{array}$ & $\begin{array}{l}(163) \\
(778) \\
(152) \\
(170) \\
(162)\end{array}$ & $\begin{array}{l}7 \cdot 26 \pm 0.50 \\
7.10 \pm 0.53 \\
6.85 \pm 0.40 \\
5.28 \pm 0.22 \dagger \\
4.75 \pm 0.22\end{array}$ & $\begin{array}{l}(161) \\
(773) \\
(138) \\
(164) \\
(153)\end{array}$ \\
\hline
\end{tabular}

Values given as mean $\pm \mathrm{SEM}$

*Significant difference from previous time of testing $(p<0 \cdot 01)$.

+Significant difference from previous time of testing $(p<0.001)$.

$(n)=$ number of subjects tested.

Ninety six of the patients had evidence of active haemolysis, while in 58 cases haemolysis was not suggested. Since most (140) of the patients' samples were tested on either day 0 or day 1 , only the results at these times were considered in the analysis; they are shown in Tables 2 and 3, together with their statistical significance.

\section{Discussion}

The introduction of a reliable and rapid method of estimating red cell adenine nucleotides by bioluminescence ${ }^{3}$ has allowed their measurement to be introduced into routine laboratory use. The present study is based on far larger numbers of both normal subjects and patients than any previous investigation. The results shown in Table 1 are important in establishing a range of values from normal adults at times when specimens are likely to be received in the laboratory; the effect of storage time is well illustrated. The results are of the same order as those of previous studies ${ }^{3-5}$ and it should be noted that values did not vary with age or sex.

In the patients with active haemolysis, the results are striking and show significantly raised ATP concentrations compared with both normal subjects and those patients with no evidence of haemolysis (Table 2). In addition to the mean age of the cells, erythrocyte ATP values depend on synthesis of adenine nucleotides by the cells, on serum inorganic phosphate concentrations, and on the rate of glycolysis.

A raised reticulocyte count obviously gives a lower mean red cell age; in addition, reticulocytes, but not mature red cells, are able to synthesise adenine nucleotides de novo. ${ }^{6}$ The effect of the reticulocyte count on the raised ATP concentrations in the patients with active haemolysis (Table 2) was therefore examined. Linear regression analysis, relating red cell ATP $(y)$ and reticulocyte count $(x),{ }^{4}$ established the equation $y=1.77+0.019 x$ and confirmed that the raised ATP concentrations were

Table 2 Red cell adenosine triphosphate $(A T P)$ and adenosine diphosphate $(A D P)$ concentrations and $A T P$ to $A D P$ ratios for patients with active haemolysis

\begin{tabular}{|c|c|c|c|c|c|c|}
\hline Time of testing & $A T P(\mu \mathrm{mol} / \mathrm{ml})$ & $(n)$ & $A D P(\mu \mathrm{mol} / \mathrm{ml})$ & $(n)$ & $A T P: A D P$ & $(n)$ \\
\hline $\begin{array}{l}\text { Day } 0 \\
\text { Day } 1 \\
\text { Day } 2\end{array}$ & $\begin{array}{l}2.17 \pm 0.08 \dagger \ddagger \\
2.04 \pm 0.02 \dagger \S \\
2.12 \pm 0.30 \dagger\end{array}$ & $\begin{array}{l}(16) \\
(66) \\
(7)\end{array}$ & $\begin{array}{l}0.25 \pm 0.03 \\
0.14 \pm 0.02 \\
0.21 \pm 0.02\end{array}$ & $\begin{array}{l}(16) \\
(62) \\
(5)\end{array}$ & $\begin{array}{c}10.12 \pm 1.03 \\
9.12 \pm 0.58^{*} \\
10.90 \pm 1.16\end{array}$ & $\begin{array}{l}(16) \\
(59) \\
(5)\end{array}$ \\
\hline
\end{tabular}

Values given as mean $\pm \mathrm{SEM}$

*Significant difference from corresponding normal value $(\mathrm{p}<0.05)$.

tSignificant difference from corresponding normal value $(p<0.001)$.

¥Significant difference from corresponding Table 3 value $(\mathrm{p}<0.05)$.

\$Significant difference from corresponding Table 3 value $(\mathrm{p}<0.001)$.

$(n)=$ number of subjects tested.

Table 3 Red cell adenosine triphosphate $(A T P)$ and adenosine diphosphate $(A D P)$ concentrations and $A T P$ to $A D P$ ratios for patients with no evidence of haemolysis

\begin{tabular}{|c|c|c|c|c|c|c|}
\hline Time of testing & $A T P(\mu \mathrm{mol} / \mathrm{ml})$ & (n) & $A D P(\mu \mathrm{mol} / \mathrm{ml})$ & (n) & $A T P: A D P$ & $(n)$ \\
\hline $\begin{array}{l}\text { Day } 0 \\
\text { Day } 1\end{array}$ & $\begin{array}{l}1.76 \pm 0.15^{*} \\
1.57 \pm 0.05 \dagger\end{array}$ & $\begin{array}{l}(8) \\
(43)\end{array}$ & $\begin{array}{l}0.19 \pm 0.02 \\
0.21 \pm 0.04\end{array}$ & $\begin{array}{l}(8) \\
(35)\end{array}$ & $\begin{array}{r}12.48 \pm 3.74 \\
7.98 \pm 0.70\end{array}$ & $\begin{array}{l}(8) \\
(35)\end{array}$ \\
\hline
\end{tabular}

Values given as mean \pm SEM

*Significant difference from corresponding normal value $(p<0.05)$

tSignificant difference from corresponding normal value $(\mathrm{p}<0.001)$.

$(n)=$ number of subjects tested. 
dependent on the reticulocytosis (mean reticulocyte count $15.6 \% ; \mathrm{r}=0.05, \mathrm{p}<0.01)$ but that this would account for only about $23 \%$ of the increase.

High serum concentrations of inorganic phosphate, which raise erythrocyte ATP values by stimulating glycolysis - for example, in patients with renal failure ${ }^{4}$ and in children ${ }^{7}$-are not seen in patients with autoimmune haemolysis (in the absence of renal failure). All of 16 patients with profound autoimmune haemolysis seen recently at this centre had inorganic phosphate concentrations within the normal range (mean $\pm \mathrm{SEM}=1.05 \pm$ $0.03 \mathrm{mmol} / \mathrm{l}$; normal range $0 \cdot 60-1 \cdot 50)$.

Although anaemia itself may cause increased glycolysis,' it is thought unlikely in the present cases that the autoantibody coating effected changes in the glycolytic rate which contributed significantly to the raised ATP concentrations (Table 2). Comparatively little work has been carried out on this subject and the results are conflicting. Incubating rhesus D positive erythrocytes with anti-D decreased their glycolytic rate, ${ }^{89}$ though this was not seen using group $\mathbf{A}$ cells and anti- $\mathbf{A} .^{8}$ In other experiments with $A$ cells and anti- $\mathbf{A}$, erythrocyte membrane ATPase activity was increased, resulting in reduced ATP concentrations. ${ }^{10}$ The slightly higher concentrations of red cell ATP found in infants with severe erythroblastosis fetalis compared with normal infants, however, were thought to result from alterations in glycolysis rather than from relative immaturity of erythrocytes ${ }^{11}$; ATPase activity has been reported to be normal in such cases. ${ }^{12}$

It therefore seems likely that the raised ATP concentrations in Table 2 mainly reflect decreased mean red cell age due to active haemolysis. Five patients in this group, however, had ATP concentrations within the normal range; their records were reexamined. Three patients had mild haemolysis and another had C3d coated cells, which have a near normal life span ${ }^{13}$; there was no obvious explanation for the normal ATP concentration in the one remaining patient, who had pronounced haemolysis.

Although most patients in the non-haemolysing group had normal erythrocyte ATP contents, high concentrations in 11 cases (none greatly raised) were sufficient to increase the mean value significantly (Table 3 ). Nine of these patients had the anaemia of chronic disorders, ${ }^{14}$ while on reexamination the other two probably had subclinical haemolysis. Moderately raised erythrocyte ATP concentrations have been reported previously in patients with chronic disorders, ${ }^{4}$ and since features of this condition include decreased red cell life span $^{14}$ and mild reticulocytosis, ${ }^{4}$ the findings in Table 3 do not contradict the view that ATP concentrations relate to mean red cell age.

We conclude that, provided the serum inorganic phosphate concentration is normal, measurement of red cell ATP is a useful indicator of mean erythrocyte age in patients with erythrocyte autoantibodies, including cases with reticulocytopenia, and that a raised concentration reflects active haemolysis.

We thank Dr MJ Brown, Dr DJ Clark, Dr EA French, Dr ML Ghosh, Dr RM Hutchinson, Dr PAE Jones, Dr ACK Lawrence, Dr JS Lilleyman, Dr S Mayne, Dr DC Mitchell, Dr F Murphy, Dr WR Parry, Dr D Prangnell, Dr FE Preston, Dr S Sobolewski, Dr KR Speed, Dr RM Stewart, Dr RB Tattersall, Dr JG Tetley, Dr A St J Wilding, and Dr DA Winfield for providing clinical details; Fran Gillett and Dr W Wagstaff for helpful advice; and Miss JE Stobbs for secretarial assistance.

\section{References}

' Petz LD, Garratty G. Acquired immune hemolytic anemias. New York: Churchill Livingstone, 1980.

${ }^{2}$ Eaton JW, Brewer GJ. Pentose phosphate metabolism. In: Surgenor DM, ed. The red blood cell, 2nd ed. New York: Academic Press, 1974;435-71.

${ }^{3}$ Summerfield GP, Keenan JP, Brodie NJ, Bellingham AJ. Bioluminescent assay of adenine nucleotides: rapid analysis of ATP and ADP in red cells and platelets using the LKB luminometer. Clin Lab Haematol 1981;3:257-71.

4 Lichtman MA, Miller DR, Weed RI. Energy metabolism in uremic red cells: relationship of red cell adenosine triphosphate concentration to extracellular phosphate. Trans Assoc Am Phys 1969;82:331-43.

s Olsson T, Guilliksson H, Palmeborn M, Bergstrom K, Thore A. Methodological aspects on the firefly luciferase assay of adenine nucleotides in whole blood and red blood cells. Scand J Clin Lab Invest 1983;43:657-64.

- Gordon-Smith EC. Hereditary defects in red cell metabolism. In: Hoffbrand AV, Lewis SM, eds. Tutorials in post-graduate medicine, 1: Haematology. London: William Heinemann. 1972;148-83.

7 Brewer GJ. Red cell metabolism and function. In: Surgenor DM, ed. The red blood cell. 2nd ed. New York: Academic Press, 1974:473-508.

${ }^{8}$ Storti E, Vaccari F, Baldini E. Changes in red cell metabolism in presence of incomplete antibodies. Experimentia 1955;12:108-9.

' Abrahamov A, Diamond LK. Erythrocyte glycolysis in erythroblastic newborns. Am J Dis Child 1960;95:202-5.

${ }^{10}$ Palek J, Mirćevová L, Brabec V, Friedmann B, Májský A. The effect of anti $A$ antibody on red cell organic phosphates and adenosine triphosphatase activity in vitro. Scand $J$ Haematol 1968;5:191-210.

" Greenwalt TJ, Morell SA, Ayers VE. Phosphate partition in the erythrocytes of normal newborn infants and infants with erythroblastosis fetalis. IV. Ion exchange chromatography. Blood 1963;22:589-99.

${ }^{12}$ Letarte J, Shahidi NT, Hitzig WH. L'activité de l'adenosinetriphosphatase chez les individus normaux et les malades atteints d'anemie hemolytique. Schweiz Med Wochenschr 1965;95: 1440-2.

${ }^{13}$ Engelfriet $\mathrm{CP}, \mathrm{Kr}$ von dem Borne AEG, Beckers D, et al. Immune destruction of red cells. In: Bell CA ed. A seminar on immune-mediated cell destruction. Washington DC: American Association of Blood Banks, 1981;93-130.

14 Cartwright GE, Lee GR. The anaemia of chronic disorders. $\mathrm{Br} J$ Haematol 1971;21:147-52.

Requests for reprints to: Dr RJ Sokol, Regional Blood Transfusion Centre, Longley Lane, Sheffield S5 7JN, England. 